\title{
Improvement of the effective work function and transmittance of thick indium tin oxide/ultrathin ruthenium doped indium oxide bilayers as transparent conductive oxide
}

Kattareeya Taweesup ${ }^{1}$, Ippei Yamamoto ${ }^{2,3}$, Toyohiro Chikyow ${ }^{2}$, Gobboon Lothongkum ${ }^{1}$, Kazutoshi Tsukagoshi ${ }^{2}$, Tomoji Ohishi ${ }^{3}$, Sukkaneste Tungasmita ${ }^{4}$, Patama Visuttipitukul ${ }^{1}$, Kazuhiro Ito ${ }^{5}$, Makoto Takahashi ${ }^{5}$, and Toshihide Nabatame ${ }^{2,6 *}$.

1. Department of Metallurgical Engineering, Faculty of Engineering, Chulalongkorn University, Bangkok 10330, Thailand.

2. International Center for Materials Nanoarchitectonics (WPI-MANA), National Institute for Materials Science (NIMS), 1-1 Namiki, Tsukuba, Ibaraki 305-0044, Japan.

3. Shibaura Institute of Technology, 3-7-5 Toyosu, Koto, Tokyo 135-8548, Japan.

4. Graduate School of Science, Department of Physics, Faculty of Science, Chulalongkorn University, Bangkok 10330, Thailand.

5. Joining and Welding Research Institute, Osaka University, 11-1 Mihogaoka, Ibaraki, Osaka 567-0047, Japan

6. CREST, Japan Science and Technology Agency, 4-1-8 Honcho, Kawaguchi, Saitama 332-0012, Japan.

*Corresponding author: NABATAME.Toshihide@ @ims.go.jp

$$
\text { Phone: +81-29-860-4915 }
$$

$$
\text { Fax: }+81-29-860-4838
$$

International Center for Materials Nanoarchitectonics (WPI-MANA), National Institute for Materials Science (NIMS), 1-1 Namiki, Tsukuba, Ibaraki 305-0044, Japan 


\begin{abstract}
Ruthenium doped indium oxide $\left(\operatorname{In}_{1-x} \mathrm{Ru}_{\mathrm{x}} \mathrm{O}_{\mathrm{y}}\right)$ films fabricated using DC magnetron co-sputtering with $\mathrm{In}_{2} \mathrm{O}_{3}$ and $\mathrm{Ru}$ targets were investigated for use as transparent conductive oxides. The $\operatorname{In}_{1-\mathrm{x}} \mathrm{Ru}_{\mathrm{x}} \mathrm{O}_{\mathrm{y}}$ films had an amorphous structure in the wide compositional range of $\mathrm{x}=$ 0.3-0.8 and had an extremely smooth surface. The transmittance and resistivity of the $\mathrm{In}_{1-\mathrm{x}} \mathrm{Ru}_{\mathrm{x}} \mathrm{O}_{\mathrm{y}}$ films increased as the $\mathrm{Ru}$ content increased. The transmittance of the $\operatorname{In}_{0.38} \mathrm{Ru}_{0.62} \mathrm{O}_{\mathrm{y}}$ film improved to over $80 \%$ when the film thickness was less than $5 \mathrm{~nm}$, while the specific resistivity $(\rho)$ was kept to a low value of $1.6 \times 10^{-4} \Omega \mathrm{cm}$. Based on these experimental data, we demonstrated that thick indium tin oxide $\left(\mathrm{In}_{0.9} \mathrm{Sn}_{0.1} \mathrm{O}_{\mathrm{y}}\right.$, ITO) $(150 \mathrm{~nm}) / \mathrm{ultrathin} \mathrm{In}_{0.38} \mathrm{Ru}_{0.62} \mathrm{O}_{\mathrm{y}}(3$ $\mathrm{nm}$ ) bilayers have a high effective work function of $5.3 \mathrm{eV}$, transmittance of $86 \%$, and low $\rho$ of $9.2 \times 10^{-5} \Omega \mathrm{cm}$. This ITO/ $/ \mathrm{In}_{0.38} \mathrm{Ru}_{0.62} \mathrm{O}_{\mathrm{y}}$ bilayer is a candidate for use as an anode for organic electroluminescent devices.
\end{abstract}

Keywords: Ru-doped $\operatorname{In}_{2} \mathrm{O}_{3}$; Transparent conductive oxide; Effective work function; $\mathrm{ITO} / \mathrm{In}_{0.38} \mathrm{Ru}_{0.62} \mathrm{O}_{\mathrm{y}}$ bilayer

\title{
1. Introduction
}

Transparent conductive oxides are commonly applied as anodes in organic electroluminescent (OEL) devices. The properties required in a perfect anode material are a low electrical resistivity, high transmittance in the visible range, excellent surface contact, and a high work function $(\varnothing)$. Currently, indium tin oxide $\left(\operatorname{In}_{0.9} \mathrm{Sn}_{0.1} \mathrm{O}_{\mathrm{y}}\right.$, ITO) is the most attractive anode material; however, ITO has a low $\varnothing$ of $4.7 \mathrm{eV}$ [1]. A $\varnothing$ of over $5 \mathrm{eV}$ is required for an anode because the highest occupied molecular orbital of a hole transport layer is usually over $5 \mathrm{eV}$. 
Additionally, an anode with a high $\varnothing$ can reduce the potential barrier, allowing efficient hole injection, which can decrease the operating voltage of the device.

For these reasons, several approaches have been proposed to improve the $\varnothing$ of ITO and to develop a new anode material. One approach is to introduce oxygen to replenish the oxygen deficiency of ITO films using surface treatment techniques such as oxygen plasma, oxidation annealing, and laser irradiation [2-4]. The work function increases as the oxygen concentration increases [3]. Another popular method is to dope with high work function elements such as Mo, $\mathrm{Ni}, \mathrm{W}$, and Pt in an $\mathrm{In}_{2} \mathrm{O}_{3}$ film to enhance the $\varnothing$ [5-7]. This method is effective in increasing $\varnothing$ and lowering the electrical resistivity. However, there is a trade-off between $\varnothing$ and the transmittance because $\varnothing$ increases and the transmittance reduces when the amount of the doping element increases.

We observed that ruthenium oxide $\left(\mathrm{RuO}_{2}\right)$ is an interesting material because of its high effective work function $\left(\varnothing_{\mathrm{m}, \mathrm{eff}}\right)$ over $5 \mathrm{eV}$ [8]. However, the low transmittance is a big issue when considering using $\mathrm{RuO}_{2}$ as an anode. We expect that $\mathrm{Ru}$-doped $\operatorname{In}_{2} \mathrm{O}_{3}\left(\operatorname{In}_{1-\mathrm{x}} \mathrm{Ru}_{\mathrm{x}} \mathrm{O}_{\mathrm{y}}\right)$ will affect the $\emptyset_{\mathrm{m} \text {,eff }}$. The $\emptyset_{\mathrm{m}, \mathrm{eff}}$ value of an electrode is determined by the electrode/insulator interface rather than the top surface and bulk of the electrode [8-10]. Therefore, it is of great interest to determine if a bilayer of thick ITO and thin $\operatorname{In}_{1-x} \mathrm{Ru}_{\mathrm{x}} \mathrm{O}_{\mathrm{y}}$ can carry enough current as an anode while the $\emptyset_{\mathrm{m}, \text { eff }}$ value of the $\mathrm{In}_{1-\mathrm{x}} \mathrm{Ru}_{\mathrm{x}} \mathrm{O}_{\mathrm{y}}$ is maintained.

In this paper, the influence of $\mathrm{Ru}$ content on the electrical and physical characteristics of the $\operatorname{In}_{1-x} \mathrm{Ru}_{\mathrm{x}} \mathrm{O}_{\mathrm{y}}$ films is reported. We also discuss the usefulness of an ITO/In ${ }_{1-x} \mathrm{Ru}_{\mathrm{x}} \mathrm{O}_{\mathrm{y}}$ bilayer as a transparent conductive oxide.

\section{Experimental Details}

\section{$2.1 \operatorname{In}_{1-x} R u_{x} O_{y}$ thin film preparation}


$P$-type $\mathrm{Si}$ with a 100 -nm-thick $\mathrm{SiO}_{2}$ layer and synthetic quartz were used as substrates to evaluate the specific resistivity, transmittance, and surface roughness of the samples. The $\mathrm{In}_{1-\mathrm{x}} \mathrm{Ru}_{\mathrm{x}} \mathrm{O}_{\mathrm{y}}$ thin films were deposited on substrates at room temperature under a working pressure of $0.5 \mathrm{~Pa}$ in an $\mathrm{Ar} / \mathrm{O}_{2}(30 / 10)$ atmosphere by DC magnetron co-sputtering using $\mathrm{In}_{2} \mathrm{O}_{3}(99.99 \%)$ and pure $\mathrm{Ru}(99.90 \%)$ targets. The sputtering targets were 3 inches in diameter. The substrates were rotated at a rate of $18.5 \mathrm{rpm}$ during sputtering. The composition of the $\operatorname{In}_{1-\mathrm{x}} \mathrm{Ru}_{\mathrm{x}} \mathrm{O}_{\mathrm{y}}$ thin films was varied by changing the sputtering power of each target as listed in Table 1.

\subsection{Fabrication of $\mathrm{SiO}_{2} \mathrm{MOS}$ capacitors with a ITO/In $n_{0.38} \mathrm{Ru} u_{0.62} \mathrm{O}_{y}$ bilayer electrode}

ITO/In ${ }_{0.38} \mathrm{Ru}_{0.62} \mathrm{O}_{\mathrm{y}}$-gated metal-oxide-semiconductor (MOS) capacitors were prepared to examine the $\emptyset_{\mathrm{m} \text {,eff }}$ of the $\mathrm{In}_{0.38} \mathrm{Ru}_{0.62} \mathrm{O}_{\mathrm{y}}$ films. Thermal $\mathrm{SiO}_{2}$ layers of different thicknesses from 6.9 to $12.0 \mathrm{~nm}$ were formed using a conventional furnace at $950{ }^{\circ} \mathrm{C}$ in an $\mathrm{O}_{2}$ atmosphere. To fabricate an ITO/ $\mathrm{In}_{0.38} \mathrm{Ru}_{0.62} \mathrm{O}_{\mathrm{y}}$ bilayer as a gate electrode, a 3-nm $\mathrm{In}_{0.38} \mathrm{Ru}_{0.62} \mathrm{O}_{\mathrm{y}}$ ultrathin film was deposited on the $\mathrm{SiO}_{2}$ layers. Subsequently, a 150-nm-thick ITO film was deposited on a $\mathrm{In}_{0.38} \mathrm{Ru}_{0.62} \mathrm{O}_{\mathrm{y}}$ film at room temperature under a working pressure of $0.5 \mathrm{~Pa}$ in an $\mathrm{Ar} / \mathrm{O}_{2}$ (19.2/0.8) atmosphere with a deposition power of $200 \mathrm{~W}$ by radio frequency sputtering using an $\mathrm{In}_{0.9} \mathrm{Sn}_{0.1} \mathrm{O}_{\mathrm{y}}$ target. This bilayer electrode was patterned using photolithography and lift-off processes. The area of each square bilayer electrode was $6400 \mu \mathrm{m}^{2}$. Finally, post-metallization annealing (PMA) was performed at $300{ }^{\circ} \mathrm{C}$ for $10 \mathrm{~min}$ in $\mathrm{N}_{2}$ to suppress the influence of fixed charge at the $\mathrm{SiO}_{2} / \mathrm{Si}$ interface. ITO-gated $\mathrm{SiO}_{2}$ MOS capacitors were also prepared by the same photolithography, lift-off and PMA processes as reference.

\subsection{Characterization of the $\operatorname{In}_{1-x} R u_{x} O_{y}$ thin films}

An X-ray diffractometer (XRD, Bruker D8 discover) using $\mathrm{CuK} \alpha$ radiation was employed to examine the crystal structure and phase formation of the films. The morphology of the $\mathrm{ITO} / \mathrm{In}_{0.38} \mathrm{Ru}_{0.62} \mathrm{O}_{\mathrm{y}} / \mathrm{SiO}_{2} / \mathrm{p}-\mathrm{Si}$ capacitor was observed by transmission electron microscopy (TEM, JEM-2100F) operating at $200 \mathrm{kV}$. Each elemental mapping of the capacitor was 
evaluated by energy dispersive X-ray spectroscopy (EDX) instrument combined with TEM. Surface morphology and roughness were observed using atomic force microscopy (AFM, SI-DF40P2). The transmittance of the oxide films was measured using a spectroscopic ellipsometer (M-2000 ${ }^{\mathrm{TM}}$ XLS-100 D2) with a quartz tungsten halogen light source. The specific resistivity $(\rho)$ of the oxide films was measured with a four-terminal specific resistance tester (four-point probe resistivity processor, $\Sigma-5+$ ). The electrical properties of the MOS capacitors were determined using capacitance-voltage $(\mathrm{C}-\mathrm{V})$ measurements performed with a semiconductor parameter analyzer (Keithley $4200 \mathrm{SCS})$. Flat-band voltage $\left(V_{\mathrm{fb}}\right)$ and the equivalent oxide thickness (EOT) were estimated from the $\mathrm{C}-\mathrm{V}$ characteristics using MIRAI-ACCEPT software to determine $\emptyset_{\mathrm{m}, \mathrm{eff}}$.

\section{Results and discussion}

\subsection{Structure and surface morphology of $\operatorname{In}_{1-x} R u_{x} O_{y}$ thin films}

The chemical composition of the $\operatorname{In}_{1-x} \mathrm{Ru}_{\mathrm{x}} \mathrm{O}_{\mathrm{y}}$ thin films was estimated from the deposition rate summarized in Table 1 . The twelve thin films were prepared by changing the sputtering power of $\operatorname{In}_{2} \mathrm{O}_{3}$ and $\mathrm{Ru}$ targets. Figure 1 shows the XRD profiles of the $\operatorname{In}_{1-\mathrm{x}} \mathrm{Ru}_{\mathrm{x}} \mathrm{O}_{\mathrm{y}}$ thin films on $\mathrm{SiO}_{2} / \mathrm{Si}$ substrates. The structure of the pure $\mathrm{In}_{2} \mathrm{O}_{3}$ and $\mathrm{RuO}_{2}$ films is a result of the body-centered cubic (BCC) crystal structure of $\mathrm{In}_{2} \mathrm{O}_{3}$ and tetragonal crystal structure of $\mathrm{RuO}_{2}$ [11-13]. The XRD peaks of the $\operatorname{In}_{0.95} \mathrm{Ru}_{0.05} \mathrm{O}_{\mathrm{y}}$ film are consistent with the (211), (222), and (332) planes of the BCC structure of $\operatorname{In}_{2} \mathrm{O}_{3}$. As the Ru content increased in the $\operatorname{In}_{2} \mathrm{O}_{3}$ films, the peaks from the BCC phase gradually decreased in intensity and eventually broadened. The XRD patterns revealed that increasing the content of $\mathrm{Ru}$ changed the phase structure of the films from BCC to amorphous. We found that the structure of the $\operatorname{In}_{1-\mathrm{x}} \mathrm{Ru}_{\mathrm{x}} \mathrm{O}_{\mathrm{y}}$ films could be divided into three regions: $\mathrm{BCC}$ structure of $\mathrm{In}_{2} \mathrm{O}_{3}$ with $\mathrm{Ru}$ content of $0.0-0.24$, amorphous structure with $\mathrm{Ru}$ content of $0.30-0.83$, and tetragonal structure with Ru content of 0.93-1.0. 
The reason of amorphous structure formation is thought to be due to the difference of crystal structure and volume of unit cell between pure $\operatorname{In}_{2} \mathrm{O}_{3}$ and $\mathrm{RuO}_{2} . \operatorname{In}_{2} \mathrm{O}_{3}$ has a cubic structure with $\mathrm{a}=10.12 \AA$ [14] and $\mathrm{RuO}_{2}$ has a tetragonal structure with $\mathrm{a}=4.50$ and $\mathrm{c}=3.11 \AA$ [15]. Furthermore, we noticed that the valence numbers of In and $\mathrm{Ru}$ are +3 and +4 , respectively. Doping $\mathrm{Ru}$ into $\mathrm{In}_{2} \mathrm{O}_{3}$, $\mathrm{Ru}$ and In atoms may complete each other to form their oxide compounds, and results in disorder of their oxide crystalline structures. Therefore, the amorphous structure is formed easily.

The surface morphology of the $\operatorname{In}_{1-x} \mathrm{Ru}_{\mathrm{x}} \mathrm{O}_{\mathrm{y}}$ thin films was examined using $\mathrm{AFM}$ as shown in Figure 2. The crystalline $\mathrm{In}_{2} \mathrm{O}_{3}, \mathrm{In}_{0.95} \mathrm{Ru}_{0.05} \mathrm{O}_{\mathrm{y}}$, and $\mathrm{RuO}_{2}$ films had large route mean square (RMS) roughnesses of 4.83, 2.88, and $1.66 \mathrm{~nm}$, respectively. In contrast, the surface roughness of the $\operatorname{In}_{0.38} \mathrm{Ru}_{0.62} \mathrm{O}_{\mathrm{y}}$ film was much lower $(0.69 \mathrm{~nm})$ because of its amorphous structure. The smooth surface of the $\operatorname{In}_{0.38} \mathrm{Ru}_{0.62} \mathrm{O}_{\mathrm{y}}$ film should increase the contact area with any overlayer to result in improved electroluminescence and current injection [16-18]. Therefore, surface roughness is an important factor influencing the performance of the anode.

\subsection{Transmittance and resistivity of $\operatorname{In}_{1-x} R u_{x} O_{y}$ thin films}

Figure 3(a) shows the optical transmittance of 150 -nm-thick $\operatorname{In}_{2} \mathrm{O}_{3}, \operatorname{In}_{0.95} \mathrm{Ru}_{0.05} \mathrm{O}_{\mathrm{y}}$, $\mathrm{In}_{0.38} \mathrm{Ru}_{0.62} \mathrm{O}_{\mathrm{y}}, \mathrm{In}_{0.17} \mathrm{Ru}_{0.83} \mathrm{O}_{\mathrm{y}}$, and $\mathrm{RuO}_{2}$ films on synthetic quartz substrates measured over a wavelength range of 250-1000 $\mathrm{nm}$. The $\mathrm{In}_{2} \mathrm{O}_{3}$ film had a maximum transmittance of approximately $92 \%$ at a wavelength of $600 \mathrm{~nm}$ because of its large bandgap $(3.75 \mathrm{eV})[19,20]$. The maximum transmittance of the $\mathrm{In}_{0.95} \mathrm{Ru}_{0.05} \mathrm{O}_{\mathrm{y}}$ film was slightly lower than the $\mathrm{In}_{2} \mathrm{O}_{3}$ film and was about $80 \%$ at $600 \mathrm{~nm}$. The $\mathrm{In}_{0.38} \mathrm{Ru}_{0.62} \mathrm{O}_{\mathrm{y}}, \mathrm{In}_{0.17} \mathrm{Ru}_{0.83} \mathrm{O}_{\mathrm{y}}$, and $\mathrm{RuO}_{2}$ films had a much lower transmittance of 8,2 , and $2 \%$, respectively. Considering their potential use as an anode in OEL devices, the $\operatorname{In}_{0.38} \mathrm{Ru}_{0.62} \mathrm{O}_{\mathrm{y}}$ film has the advantage of possessing a smooth surface, although higher transmittance would be desirable. 
Next, we examined the thickness dependence of the transmittance of the $\operatorname{In}_{0.38} \mathrm{Ru}_{0.62} \mathrm{O}_{\mathrm{y}}$ film, as shown in Fig. 3(b). The thickness of $\operatorname{In}_{0.38} \mathrm{Ru}_{0.62} \mathrm{O}_{\mathrm{y}}$ films was varied from 1 to $10 \mathrm{~nm}$. The transmittance increased as the film thickness decreased. For thicknesses less than $5 \mathrm{~nm}$, the maximum transmittance was more than $80 \%$. The transmittance of a 150 -nm-thick ITO film and a thick ITO $(150 \mathrm{~nm}) /$ ultrathin $\operatorname{In}_{0.38} \mathrm{Ru}_{0.62} \mathrm{O}_{\mathrm{y}}(3 \mathrm{~nm})$ bilayer are also plotted in Figure $3(\mathrm{~b})$. The ITO/ $/ \mathrm{In}_{0.38} \mathrm{Ru}_{0.62} \mathrm{O}_{\mathrm{y}}$ bilayer had a transmittance of $86 \%$, which is nearly as good as that of the ITO film at $600 \mathrm{~nm}$. These results indicate that the transmittance of an amorphous $\operatorname{In}_{0.38} \mathrm{Ru}_{0.62} \mathrm{O}_{\mathrm{y}}$ film can be improved by using a thick ITO/ultrathin $\operatorname{In}_{0.38} \mathrm{Ru}_{0.62} \mathrm{O}_{\mathrm{y}}$ bilayer.

Figure 4 shows the changes in $\rho$ and the transmittance as a function of Ru content in 150 $\mathrm{nm} \mathrm{In} \mathrm{I}_{1-\mathrm{x}} \mathrm{Ru}_{\mathrm{x}} \mathrm{O}_{\mathrm{y}}$ films. The $\rho$ values of the $\mathrm{In}_{2} \mathrm{O}_{3}, \mathrm{In}_{0.95} \mathrm{Ru}_{0.05} \mathrm{O}_{\mathrm{y}}$, and $\mathrm{In}_{0.89} \mathrm{Ru}_{0.11} \mathrm{O}_{\mathrm{y}}$ films were too high to measure, which indicated that these films are insulating. It is clear that $\rho$ and the transmittance of the $\operatorname{In}_{1-x} \mathrm{Ru}_{\mathrm{x}} \mathrm{O}_{\mathrm{y}}$ films decreases as the $\mathrm{Ru}$ content increases. The $\mathrm{In}_{1-\mathrm{x}} \mathrm{Ru}_{\mathrm{x}} \mathrm{O}_{\mathrm{y}}$ films with $\mathrm{Ru}$ content over 0.62 had significantly low $\rho$ values of around $10^{-4} \Omega \mathrm{cm}$. However, the transmittance decreases to less than $10 \%$ with $\mathrm{Ru}$ content over 0.51 . These results indicate that the $\mathrm{In}_{1-\mathrm{x}} \mathrm{Ru}_{\mathrm{x}} \mathrm{O}_{\mathrm{y}}$ film satisfies the trade-off between $\rho$ and the transmittance. We found that the low transmittance can be solved by decreasing the thickness to $5 \mathrm{~nm}$ or less. Also, the thick ITO $(150 \mathrm{~nm}) /$ ultrathin $\operatorname{In}_{0.38} \mathrm{Ru}_{0.62} \mathrm{O}_{\mathrm{y}}(3 \mathrm{~nm})$ bilayer had a low $\rho$ value of $9.2 \times 10^{-5} \Omega \mathrm{cm}$. This suggests that there is a clear interface between the ITO and $\operatorname{In}_{0.38} \mathrm{Ru}_{0.62} \mathrm{O}_{\mathrm{y}}$ layers because there is the same dominant element of indium and because of the amorphous structure of the $\mathrm{In}_{0.38} \mathrm{Ru}_{0.62} \mathrm{O}_{\mathrm{y}}$ layer. Therefore, the thick ITO and ultrathin $\mathrm{In}_{1-\mathrm{x}} \mathrm{Ru}_{\mathrm{x}} \mathrm{O}_{\mathrm{y}}$ bilayer is expected to be a good anode electrode because of the low $\rho$ and high transmittance.

\subsection{Effective work function of ITO/In $0.38 \mathrm{Ru}_{0.62} \mathrm{O}_{y}$ bilayer}

We next examined the $\mathrm{C}-\mathrm{V}$ characteristics of $\mathrm{ITO} / \mathrm{In}_{0.38} \mathrm{Ru}_{0.62} \mathrm{O}_{\mathrm{y}}$-gated $\mathrm{SiO}_{2}$ MOS capacitors to estimate $\emptyset_{\text {m,eff }}$ of the ITO/ $\operatorname{In}_{1-\mathrm{x}} \mathrm{Ru}_{\mathrm{x}} \mathrm{O}_{\mathrm{y}}$ bilayer. Fig. 5 (a) shows a cross sectional TEM image of a ITO $(150 \mathrm{~nm}) / \mathrm{In}_{0.38} \mathrm{Ru}_{0.62} \mathrm{O}_{\mathrm{y}}(3 \mathrm{~nm}) / \mathrm{SiO}_{2}(10.5 \mathrm{~nm}) / \mathrm{p}-\mathrm{Si}$ capacitor. The ITO 
layer had a rhombohedral crystal structure from XRD pattern (not shown). The $\mathrm{In}_{0.38} \mathrm{Ru}_{0.62} \mathrm{O}_{\mathrm{y}}$ layer had an amorphous structure because no halo ring and spotty electron diffraction pattern except ITO were not observed (not shown). To examine the elements distribution, the EDX elemental mapping of Si, O, In, Sn, and Ru are represented in Fig. 5(b). The corresponding EDX maps indicate that ruthenium is only located in the $\operatorname{In}_{0.38} \mathrm{Ru}_{0.62} \mathrm{O}_{\mathrm{y}}$ layer. There were no severe reactions in any of the layers because the individual layers and interface are distinct.

Figure 6(a) shows the C-V curves of ITO $(150 \mathrm{~nm}) / \mathrm{In}_{0.38} \mathrm{Ru}_{0.62} \mathrm{O}_{\mathrm{y}}(3 \mathrm{~nm})$-gated MOS capacitors with different $\mathrm{SiO}_{2}$ thicknesses from 6.9 to $12.0 \mathrm{~nm}$. The maximum capacitance decreases as the thicknesses of the $\mathrm{SiO}_{2}$ increases. The inset in Fig. 6(a) shows experimental data and an ideal simulation line without some charges for $\mathrm{SiO}_{2}(6.9 \mathrm{~nm})$ capacitor. The simulation is closely fixed to the experimental data, indicating that the fixed charges of this capacitor is negligible small. Figure 6(b) shows the relationship between the $V_{\mathrm{fb}}$ and the EOT of the capacitors with ITO/ $\operatorname{In}_{0.38} \mathrm{Ru}_{0.62} \mathrm{O}_{\mathrm{y}}$ and ITO gates. There is a linear relationship between $V_{\mathrm{fb}}$ and EOT for ITO/ $/ \mathrm{In}_{0.38} \mathrm{Ru}_{0.62} \mathrm{O}_{\mathrm{y}}$ capacitors, indicating that the charge in the $\mathrm{SiO}_{2}$ film was negligible as explained in Fig. 6(a). Then, $\emptyset_{\mathrm{m}, \mathrm{eff}}$ values were determined by extrapolating the plots of $V_{\mathrm{fb}}$ versus EOT using the following equation [21]:

$$
V_{\mathrm{fb}}=\left(\emptyset_{\mathrm{m}, \mathrm{eff}}-\emptyset_{\mathrm{si}}\right)-Q_{\mathrm{ox}} /\left(\varepsilon_{0} \varepsilon_{\mathrm{ox}}\right) \times \mathrm{EOT},
$$

where $\emptyset_{\mathrm{si}}, Q_{\mathrm{ox}}, \varepsilon_{0}$, and $\varepsilon_{\mathrm{ox}}$ are the Fermi level of the silicon substrate, a fixed charges of $\mathrm{SiO}_{2}$, the permittivity, and the dielectric constant of $\mathrm{SiO}_{2}$, respectively. The $\emptyset_{\mathrm{m}, \text { eff }}$ of the ITO/ $/ \mathrm{In}_{0.38} \mathrm{Ru}_{0.62} \mathrm{O}_{\mathrm{y}}$ bilayer was estimated to be $5.3 \mathrm{eV}$. Moreover, the $\emptyset_{\mathrm{m} \text {,eff }}$ of the ITO was determined to be $4.8 \mathrm{eV}$. This $\emptyset_{\mathrm{m} \text {,eff }}$ value of the $\mathrm{ITO} / \mathrm{In}_{0.38} \mathrm{Ru}_{0.62} \mathrm{O}_{\mathrm{y}}$ bilayer is almost equal to that of pure $\mathrm{RuO}_{2}(5.5 \mathrm{eV})$ [8] and much higher than that of ITO. The $\emptyset_{\mathrm{m} \text {,eff }}$ value of an electrode is determined only at electrode/insulator interface [8-10]. Therefore, the characteristic 
of the ultrathin $(3 \mathrm{~nm}) \mathrm{In}_{0.38} \mathrm{Ru}_{0.62} \mathrm{O}_{\mathrm{y}}$ led to this high $\emptyset_{\mathrm{m} \text {,eff }}$ value. Considering the requirements for anode materials for OEL devices, we suggest that thick ITO/ultrathin $\operatorname{In}_{0.38} \mathrm{Ru}_{0.62} \mathrm{O}_{\mathrm{y}}$ bilayers show potential for use as anode materials.

\section{Conclusion}

The electrical and physical properties of the $\operatorname{In}_{1-\mathrm{x}} \mathrm{Ru}_{\mathrm{x}} \mathrm{O}_{\mathrm{y}}$ films can be strongly modified by the $\mathrm{Ru}$ content. The 150 -nm-thick $\operatorname{In}_{1-\mathrm{x}} \mathrm{Ru}_{\mathrm{x}} \mathrm{O}_{\mathrm{y}}$ films had an amorphous structure in the wide compositional range of $x=0.3-0.8$, a low resistivity in the $x=0.62-1.0$, and high transmittance in the narrow range of $x=0.0-0.11$. The transmittance of the $\operatorname{In}_{0.38} \mathrm{Ru}_{0.62} \mathrm{O}_{\mathrm{y}}$ film was improved to over $80 \%$ when the film thickness was less than $5 \mathrm{~nm}$. We found that thick ITO (150-nm)/ultrathin $\operatorname{In}_{0.38} \mathrm{Ru}_{0.62} \mathrm{O}_{\mathrm{y}}(3 \mathrm{~nm})$ bilayers had an effective work function of $5.3 \mathrm{eV}$, high transmittance of $86 \%$, and low $\rho$ of $9.2 \times 10^{-5} \Omega \mathrm{cm}$. These data indicate that the amorphous thick ITO/ultrathin $\operatorname{In}_{0.38} \mathrm{Ru}_{0.62} \mathrm{O}_{\mathrm{y}}$ bilayers are useful for an anode of OEL devices.

\section{Acknowledgments}

K. T. and G. L. acknowledge financial support from the Thailand Research Fund and Chulalongkorn University through the Royal Golden Jubilee Ph.D. Program (Grant No. PHD/0367/2550). The authors are grateful to Mr. Kuszunori Kurishima for instruction on the use of equipment, Mr. Takayuki Kishida for the fabrication of the capacitors, Dr. Shimizu Maki, and the members of the International Center for Material Nanoarchitectonics (MANA) of the National Institute for Materials Science, Japan. A part of this work was performed under the Cooperative Research Program of Institute for Joining and Welding Research Institute, Osaka University. Part of this research was supported by CREST, JST. 


\section{References}

[1] L. Chkoda, C. Heske, M. Sokolowski, E. Umbanch, F. Steuber, J. Staudigel, M. Stößel, J. Simmerer, Work function of ITO substrates and band-offsets at the TPD/ITO interface determined by photoelectron spectroscopy, Synth. Met. 111-112 (2000) 315-319.

[2] K. H. Lee, H. W. Jang, K.-B. Kim, Y.-H. Tak, J.-L. Lee, Mechanism for the increase of indium-tin-oxide work function by $\mathrm{O}_{2}$ inductively coupled plasma treatment, J. Appl. Phys. 95 (2004) 586.

[3] M. G. Mason, L. S. Hung, C. W. Tang, S. T. Lee, K. W. Wong, M. Wang, Characterization of treated indium-tin-oxide surfaces used in electroluminescent devices, J. Appl. Phys. 86 (1999) 1688.

[4] Y.-J. Lin, Y.-M. Chen, Y.-C. Wang, Effects of KrF excimer laser irradiation on surface work function of indium-tin-oxide, J. Appl. Phys. 97 (2005) 083702.

[5] E. Elangovan, G. Goncalves, R. Martins, E. Fortunato, RF sputtered wide work function indium molybdenum oxide thin films for solar cell applications, Sol. Energy. 83 (2009) 726-731. [6] J. H. Kim, T.Y. Seong, H. K. Kim, Effects of rapid thermal annealing on electrical, optical, and structural properties of Ni-doped $\mathrm{In}_{2} \mathrm{O}_{3}$ anodes for bulk heterojunction organic solar cells, J. Vac. Sci. Technol. A 31 (2013) 021201.

[7] G. F. Li, Q. Zhang, F. Yu, C. Liu, H. R. Wu, Organic light-emitting device with surface-modified tungsten-doped indium oxide anode, Electron. Lett. 44 (2008) 13. [8] T. Nabatame, K. Segawa, M. Kadoshima, H. Takaba, K. Iwamoto, S. Kimura, Y. Nunoshige, H. Satake, T. Ohishi, A. Toriumi, The effect of oxygen in Ru gate electrode on effective work function of $\mathrm{Ru} / \mathrm{HfO}_{2}$ stack structure, Mater. Sci. Semicond. Process. 9 (2006) 975-979. 
[9] T. Nabatame, M. Kimura, H. Yamada, A. Ohi, T. Ohishi, T. Chikyow, Influence of oxygen transfer in Hf-based high-k dielectrics on flatband voltage shift, Thin Solids Films 520 (2012) $3387-3391$.

[10] T. Nabatame, Y. Nunoshige, M. Kadoshima, H. Takaba, K. Segawa, S. Kimura, H. Satake, H. Ota, T. Ohishi, A. Toriumi, Changes in effective work function of $\mathrm{Hf}_{\mathrm{x}} \mathrm{Ru}_{1-\mathrm{x}}$ alloy gate electrode, Micro. Eng. 85 (2008) 1524-1528.

[11] N. G. Pramod, S. N. Pandey, Influence of Sb doping on the structural, optical, electrical and acetone sensing properties of $\operatorname{In}_{2} \mathrm{O}_{3}$ thin films, Ceram. Int. 40 (2014) 3461-3468.

[12] T. Abe, S. Inoue, K. Watanabe, XRD and electrochemical measurements of $\mathrm{RuO}_{2}$ powder treated by using a mechanical grinding method, J. Alloys Compd. 358 (2003) 177-181.

[13] J. C. Cruz, V. Baglio, S. Siracusano, V. Antonucci , A. S. Aricò, R. Ornelas, L. Ortiz-Frade, G. Osorio-Monreal, S. M. Durón-Torres, L. G. Arriaga, Preparation and Characterization of $\mathrm{RuO}_{2}$ Catalysts for Oxygen Evolution in a Solid Polymer Electrolyte, Int. J. Electrochem. Sci. 6 (2011) 6607-6619.

[14] G. Wang, J. Park, D. Wexler, M.S. Park, J.-H. Ahn, Synthesis, characterization, and optical properties of $\operatorname{In}_{2} \mathrm{O}_{3}$ semiconductor nanowires, Inorg. Chem. 46(2007) 4778-4780.

[15] Y.-L. Chueh, C.-H. Hsieh, M.-T. Chang,L.-J. Chou, C.S. Lao, J. H. Song, J.-Y. Gan, Z.L. Wang, $\mathrm{RuO}_{2}$ nanowires and $\mathrm{RuO}_{2} / \mathrm{TiO}_{2}$ core/shell nanowires: From synthesis to mechanical, optical, electrical, and photoconductive properties, Adv. Mater. 19(2007) 143-149.

[16] S. Jung, N. G. Park, M.Y. Kwak, B. O. Kim, K. H. Choi. Y. J. Cho, Y. K. Kim, Y. S. Kim, Surface treatment effects of indium-tin oxide in organic light-emitting diodes, Opt. Mater. 21 (2003) 235-241.

[17] Y. Qiu, J. Qiao, Photostability and morphological stability of hole transporting materials used in organic electroluminescence, Thin Solid Films 372 (2000) 265-270. 
[18] J. Davenas, S. Besbes, A. Abderrahmen, N. Jaffrezic, H.B. Ouada, Surface characterisation and functionalisation of indium tin oxide anodes for improvement of charge injection in organic light emitting diodes, Thin Solid Films 516 (2008) 1341-1344.

[19] R. L. Weiher, Electrical properties of single crystals of indium oxide, J. Appl. Phys. 33 (1962) 2834.

[20] J. Hamberg, C.G. Granquist, Evaporated Sn-doped $\operatorname{In}_{2} \mathrm{O}_{3}$ films - basic optical-properties and applications to energy-efficient windows, J. Appl. Phys. 60 (1986) R123.

[21] P. Homhuan, T. Nabatame, T. Chikyow, S. Tungasmita, Effect of Y Content in $(\mathrm{TaC})_{(1-\mathrm{x})} \mathrm{Y}_{\mathrm{x}}$ Gate Electrodes on Flatband Voltage Control for Hf-Based High-k Gate Stacks, Jpn. J. Appl. Phys. 50 (2011) 10PA03.

\section{Figure captions}

Figure 1. XRD patterns of $\operatorname{In}_{1-\mathrm{x}} \mathrm{Ru}_{\mathrm{x}} \mathrm{O}_{\mathrm{y}}$ thin films on $\mathrm{SiO}_{2} / \mathrm{Si}$ substrates. The $\mathrm{Ru}$ content was varied from 0 to 1.0 .

Figure 2. AFM images of (a) $\mathrm{In}_{2} \mathrm{O}_{3}$, (b) $\mathrm{RuO}_{2}$, (c) $\mathrm{In}_{0.95} \mathrm{Ru}_{0.05} \mathrm{O}_{\mathrm{y}}$, and (d) $\mathrm{In}_{0.38} \mathrm{Ru}_{0.62} \mathrm{O}_{\mathrm{y}}$ thin films.

Figure 3. (a) The transmittance of 150 -nm-thick $\operatorname{In}_{2} \mathrm{O}_{3}, \operatorname{In}_{0.95} \mathrm{Ru}_{0.05} \mathrm{O}_{\mathrm{y}}, \operatorname{In}_{0.38} \mathrm{Ru}_{0.62} \mathrm{O}_{\mathrm{y}}$, $\mathrm{In}_{0.17} \mathrm{Ru}_{0.83} \mathrm{O}_{\mathrm{y}}, \mathrm{RuO}_{2}$ and glass substrate. (b) The transmittance of $\operatorname{In}_{0.38} \mathrm{Ru}_{0.62} \mathrm{O}_{\mathrm{y}}$ films with different thicknesses from 1 to $10 \mathrm{~nm}$, a 150-nm-thick ITO film, and an ITO (150-nm)/ $\mathrm{In}_{0.38} \mathrm{Ru}_{0.62} \mathrm{O}_{\mathrm{y}}(3-\mathrm{nm})$ bilayer.

Figure 4. The specific resistivity and transmittance as a function of $\mathrm{Ru}$ content in the $150-\mathrm{nm}$ $\mathrm{In}_{1-\mathrm{x}} \mathrm{Ru}_{\mathrm{x}} \mathrm{O}_{\mathrm{y}}$ thin films. 
Figure 5. (a) a cross sectional TEM image and (b) EDX elemental mapping of the Si, O, In, Sn, and $\mathrm{Ru}$ of a ITO/ $/ \mathrm{In}_{0.38} \mathrm{Ru}_{0.62} \mathrm{O}_{\mathrm{y}} / \mathrm{SiO}_{2} / \mathrm{p}-\mathrm{Si} \mathrm{MOS}$ capacitor

Figure 6. (a) The C-V curves of thick ITO $(150 \mathrm{~nm}) / \mathrm{ultra}$-thin $\operatorname{In}_{0.38} \mathrm{Ru}_{0.62} \mathrm{O}_{\mathrm{y}}(3 \mathrm{~nm})$-gated MOS capacitors with $\mathrm{SiO}_{2}$ layers of different thicknesses. An inset graph is comparison between experimental and simulation of capacitor with a $\mathrm{SiO}_{2} 6.9 \mathrm{~nm}$. (b) The relationship between $V_{\mathrm{fb}}$ and EOT of the ITO/ $/ \mathrm{In}_{0.38} \mathrm{Ru}_{0.62} \mathrm{O}_{\mathrm{y}}$ and ITO-gated capacitors.

\section{Table caption}

Table 1. The co-sputtering conditions and $\operatorname{In}_{1-x} \mathrm{Ru}_{\mathrm{x}} \mathrm{O}_{\mathrm{y}}$ composition estimated from the deposition rate. 
Table 1

\begin{tabular}{|c|c|c|}
\hline \multicolumn{2}{|c|}{ Sputter power (W) } & $\operatorname{In}_{1-x} R u_{x} O_{y}$ composition \\
\hline $\operatorname{In}_{2} \mathbf{O}_{3}$ & $\mathbf{R u}$ & Deposition rate \\
\hline 200 & $\mathbf{0}$ & $\operatorname{In}_{2} \mathrm{O}_{3}$ \\
\hline 200 & 20 & $\operatorname{In}_{0.95} R u_{0.05} O_{y}$ \\
\hline 100 & 20 & $\operatorname{In}_{0.89} R u_{0.11} O_{y}$ \\
\hline 100 & 50 & $\operatorname{In}_{0.76} R u_{0.24} O_{y}$ \\
\hline 50 & 20 & $\operatorname{In}_{\mathbf{0 . 7 0}} \mathbf{R u}_{0.30} \mathrm{O}_{\mathbf{y}}$ \\
\hline 50 & 50 & $\operatorname{In}_{0.49} \operatorname{Ru}_{0.51} \mathrm{O}_{\mathrm{y}}$ \\
\hline 20 & 20 & $\operatorname{In}_{0.44} R u_{0.56} O_{y}$ \\
\hline 100 & 100 & $\operatorname{In}_{0.38} R u_{0.62} O_{y}$ \\
\hline 20 & 50 & $\operatorname{In}_{0.27} \mathrm{Ru}_{0.73} \mathrm{O}_{\mathrm{y}}$ \\
\hline 20 & 100 & $\operatorname{In}_{0.17} R u_{0.83} O_{y}$ \\
\hline 20 & 100 & $\operatorname{In}_{0.07} \mathrm{Ru}_{0.93} \mathrm{O}_{\mathrm{y}}$ \\
\hline $\mathbf{0}$ & 100 & $\mathrm{RuO}_{2}$ \\
\hline
\end{tabular}




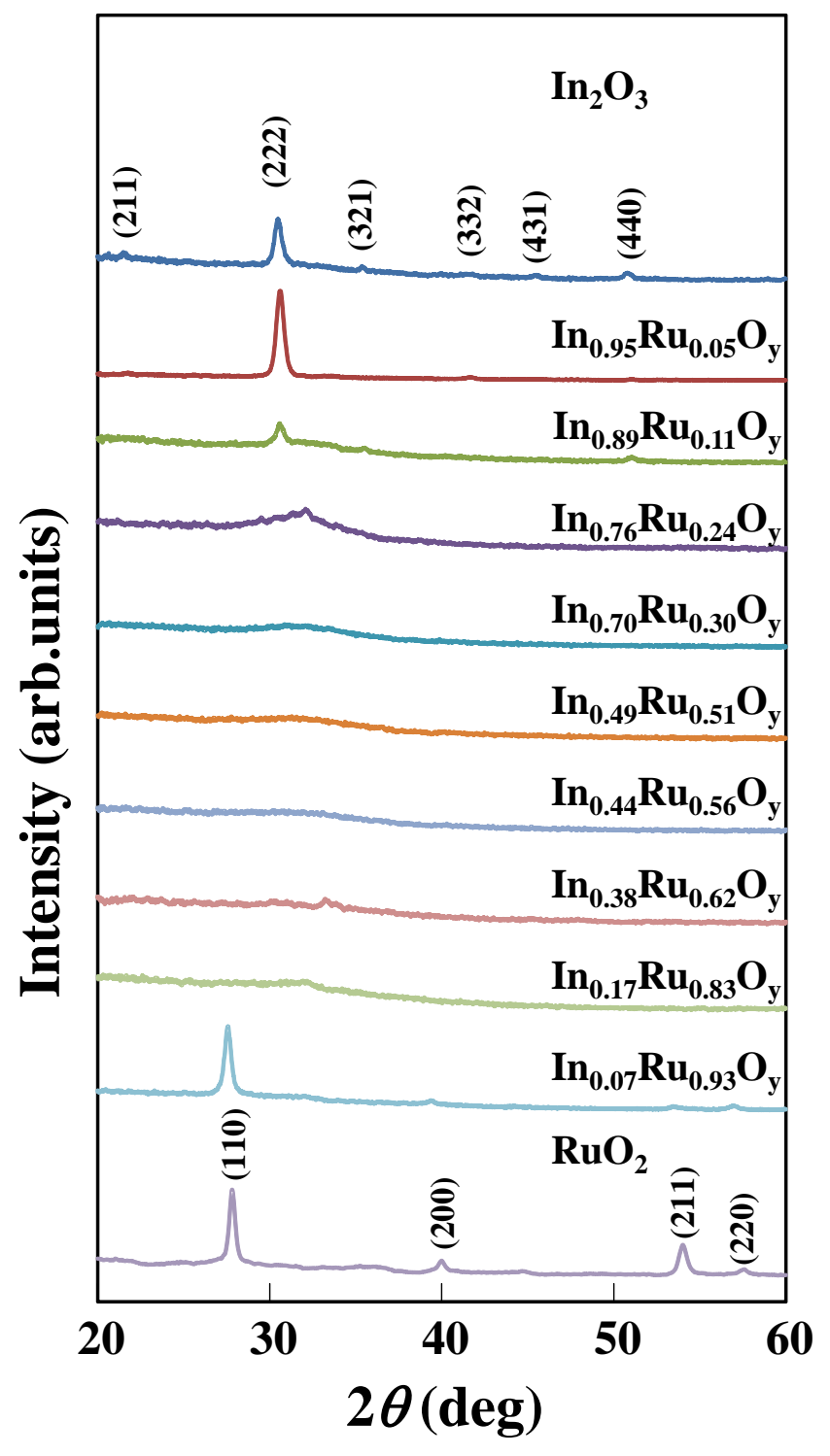

Figure 1 


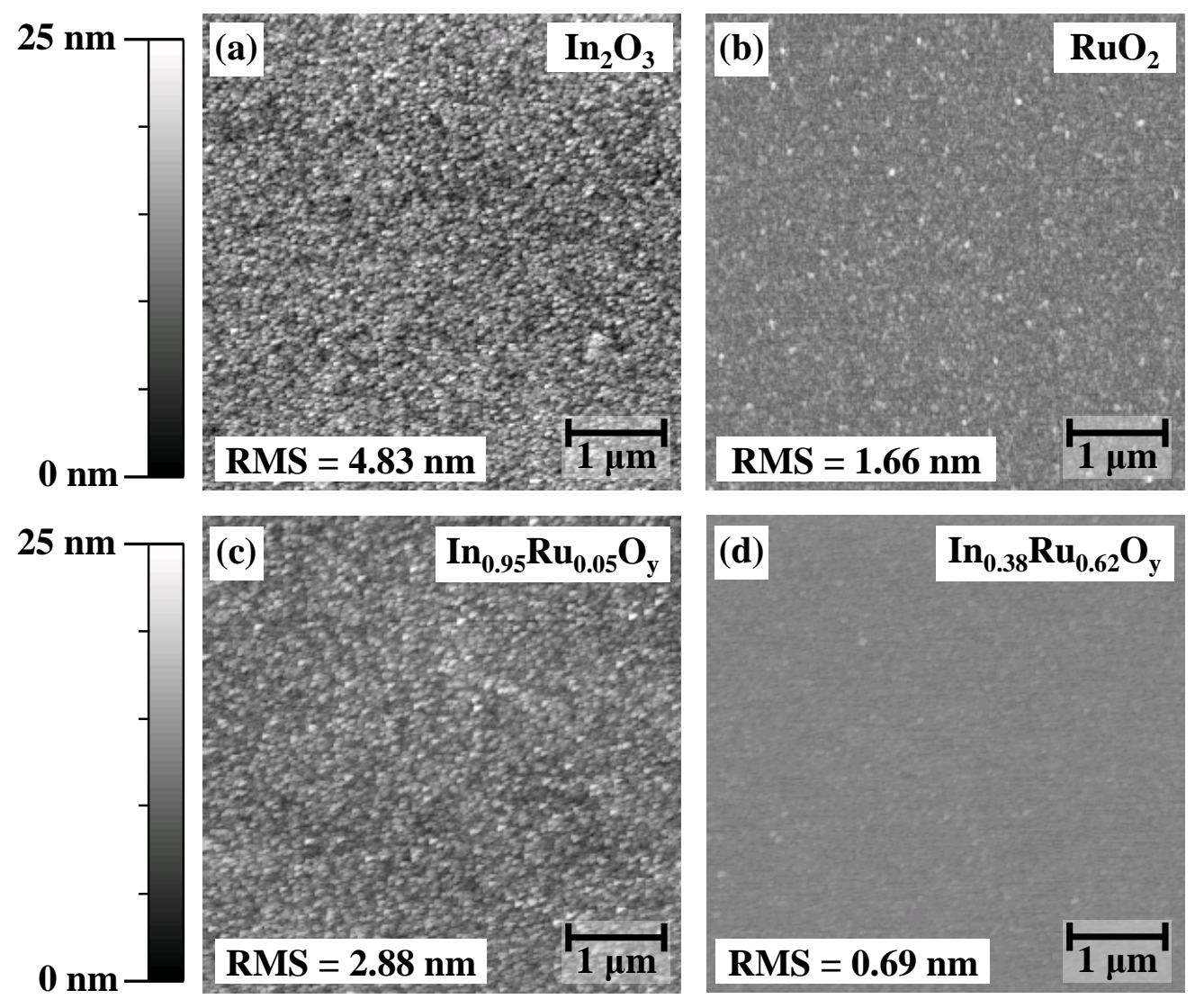

Figure 2 
(a)

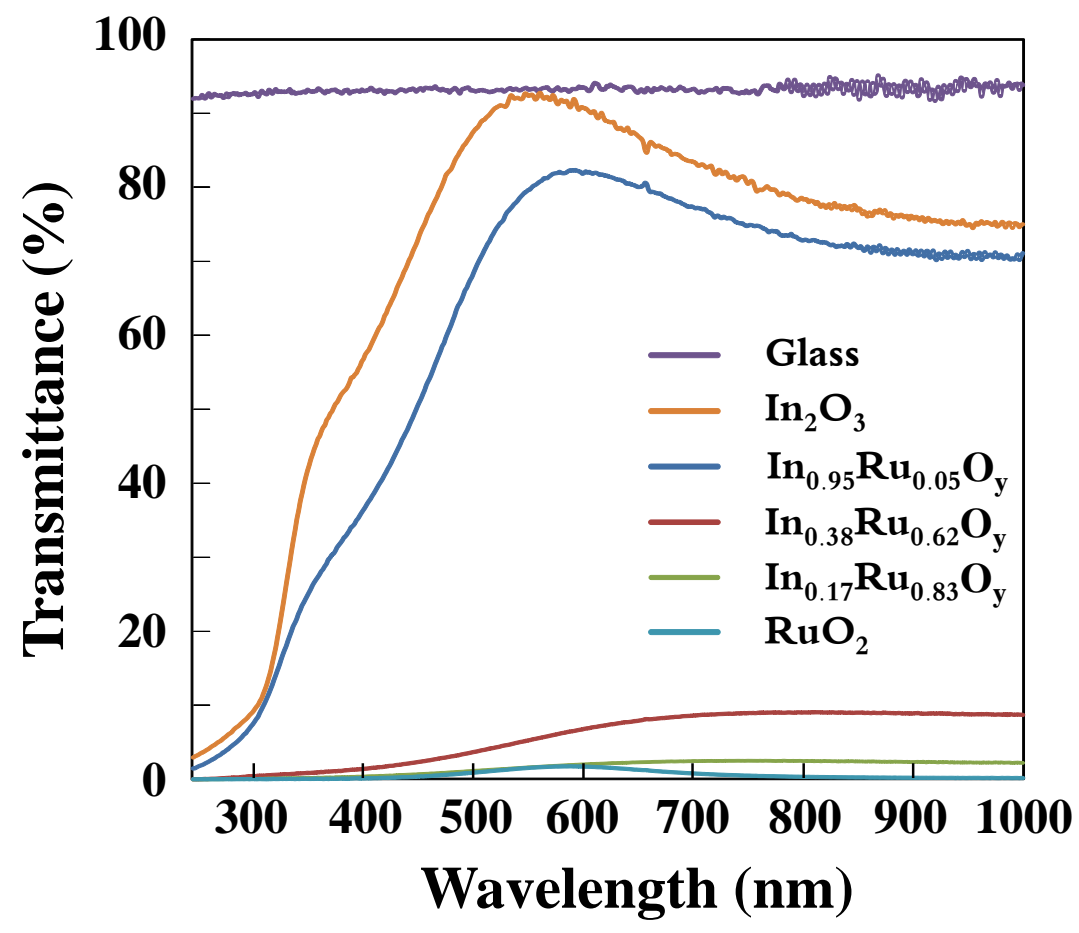

(b)

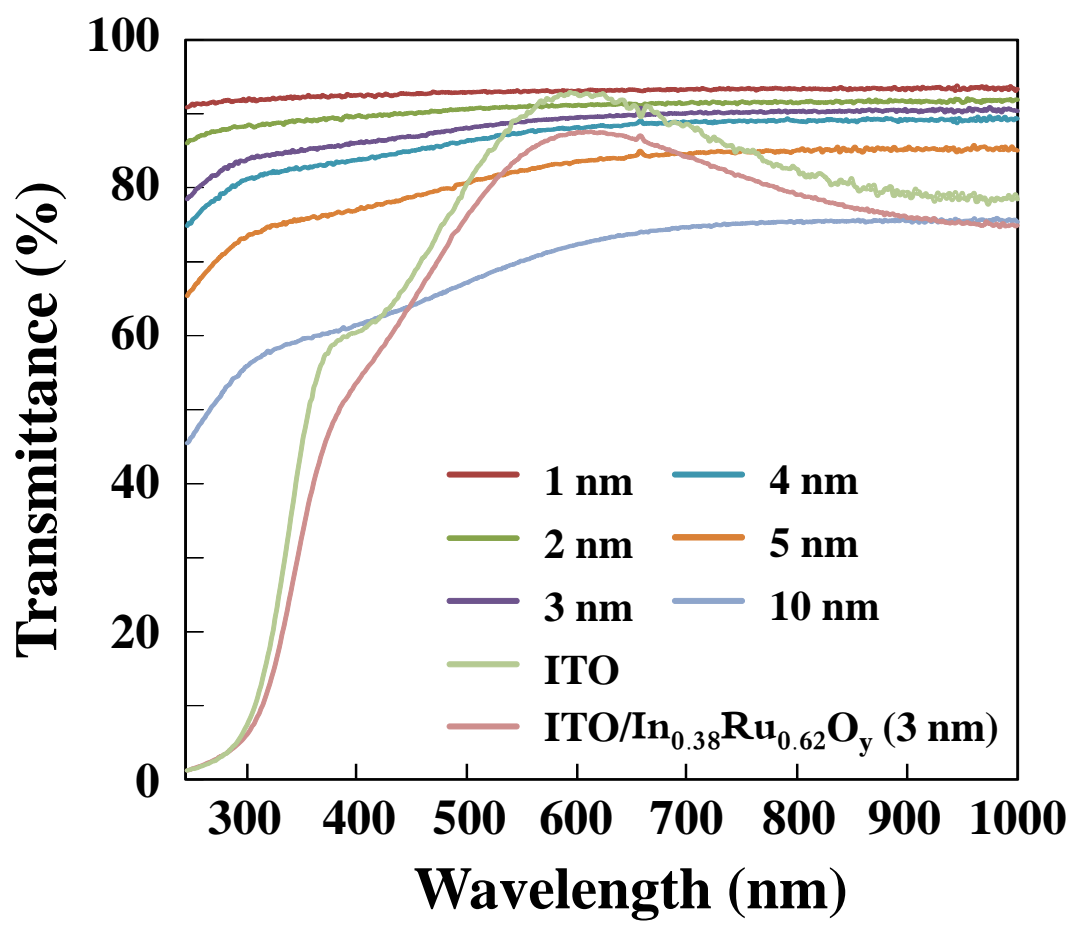

Figure 3 


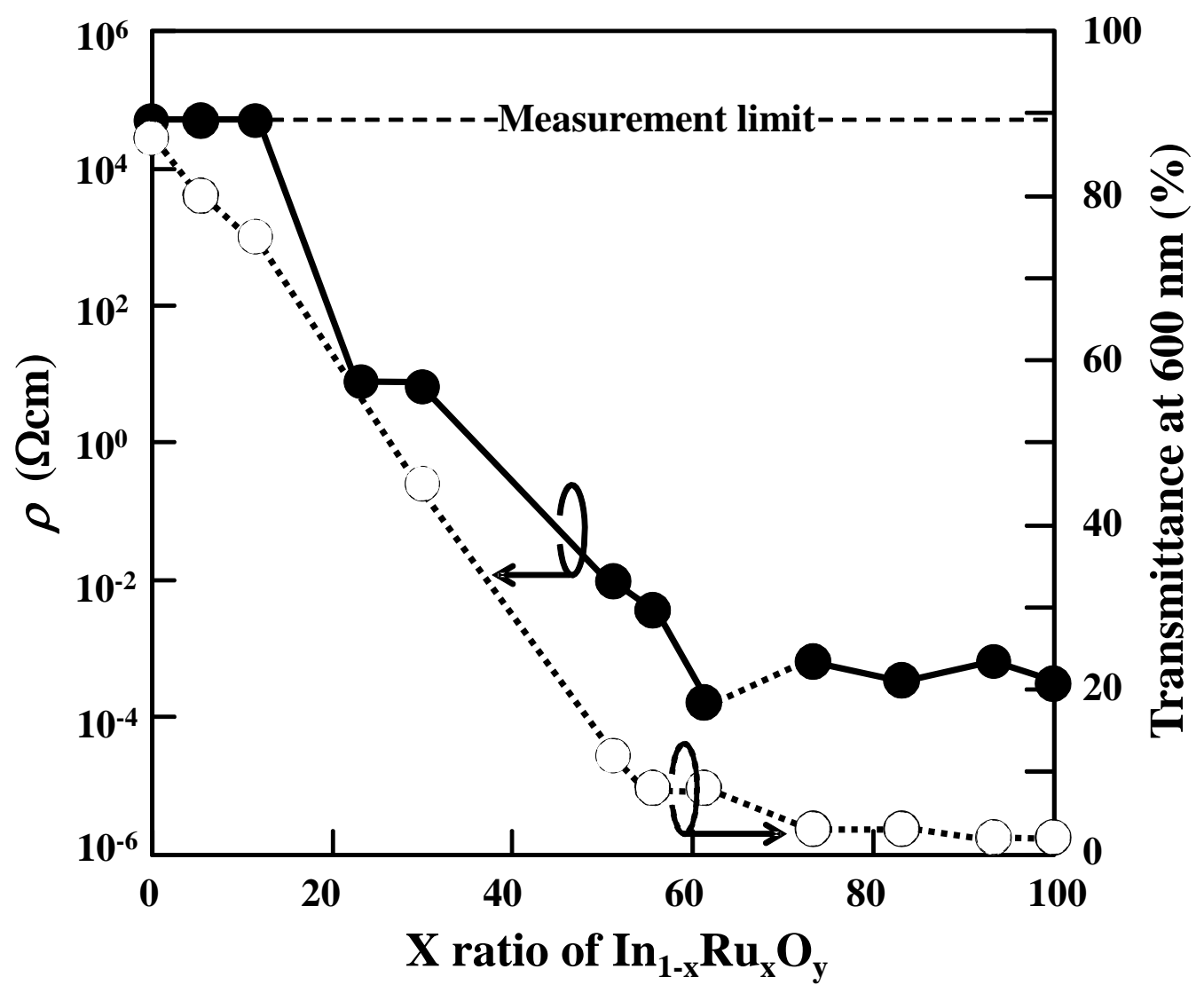

Figure 4 
(a)

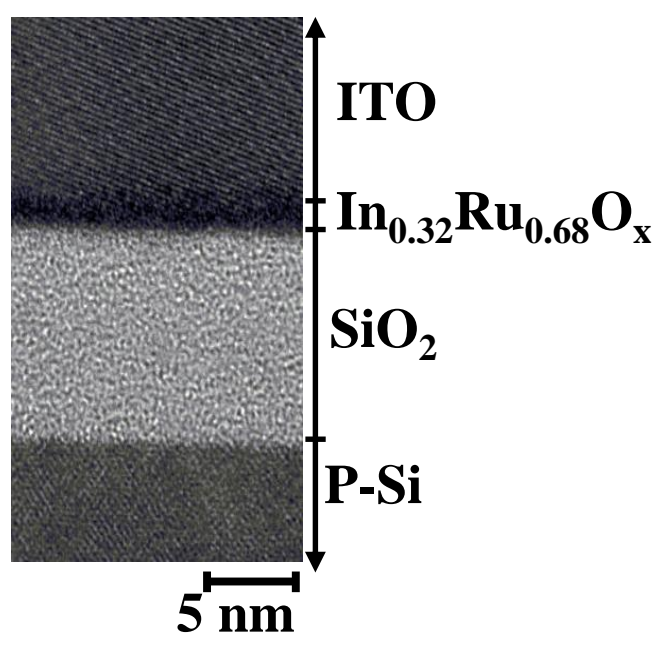

(b)

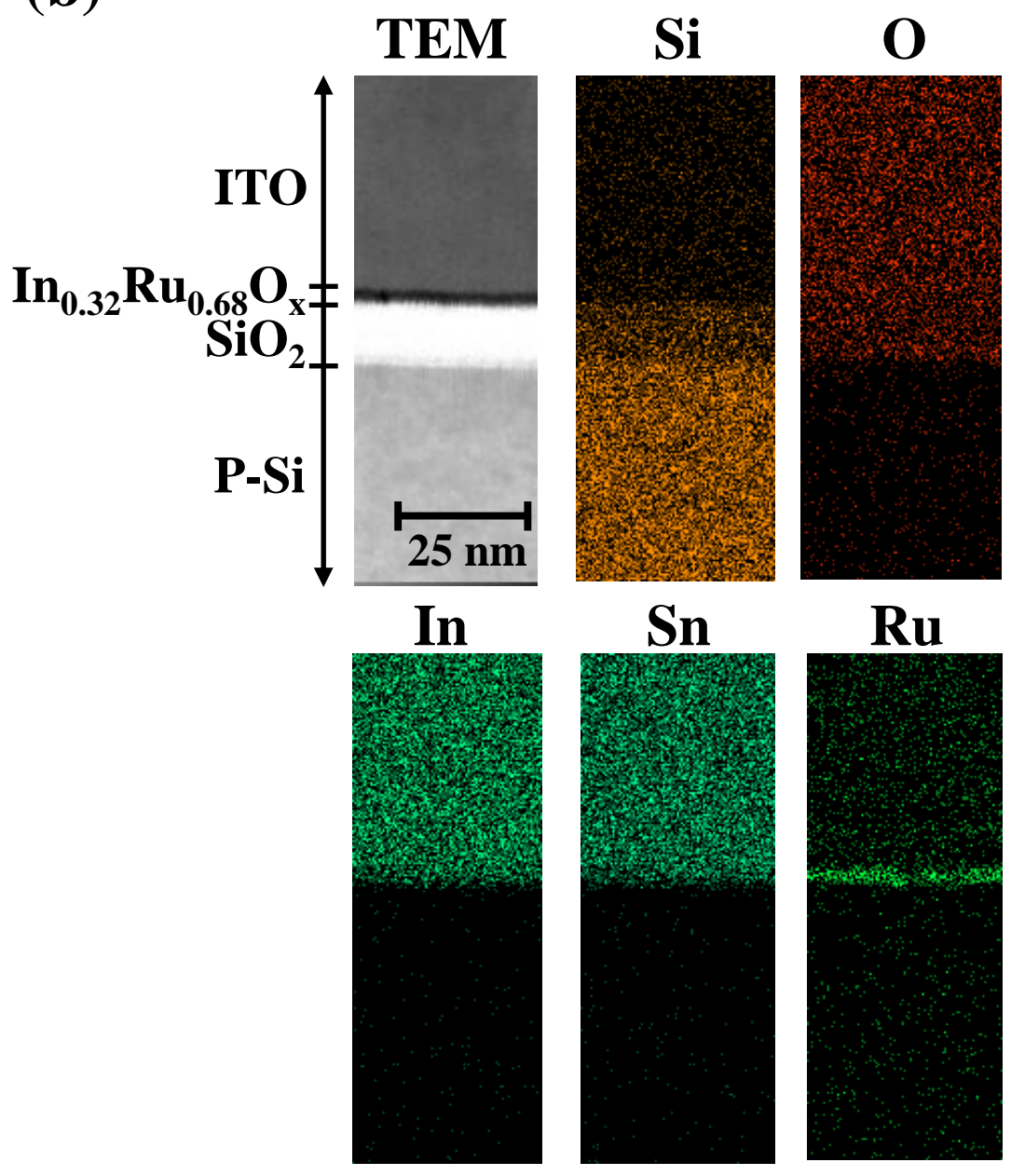

Figure 5 
(a)
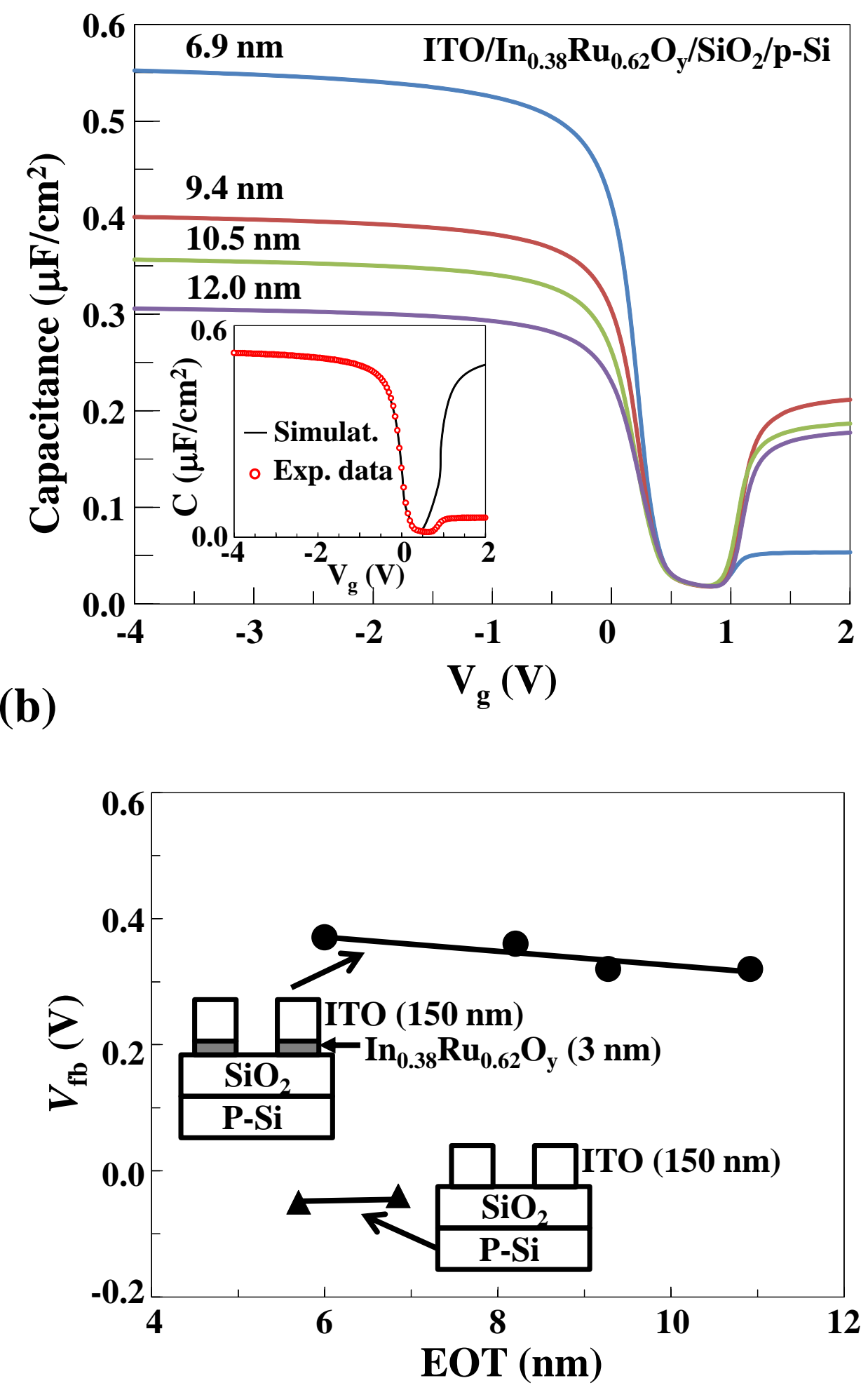

Figure 6 